\title{
Suppression of Matrix Metallopeptidase-3 Expression in Human Dermal Fibroblasts by Decursin from Angelica gigas Nakai Root Extracts Fermented with Jeju Lava Seawater
}

\author{
Jungwook Kang ${ }^{1}$, Garam Nam², Yeahwa Yoon ${ }^{2}$, Gyeongmi Kim², Sowon Bae ${ }^{2}$, Hyunjeong Lee ${ }^{2}$, Seunghee Bae ${ }^{2}$, Youngkwon Cha ${ }^{3}$, Hyundae \\ $\mathrm{Cho}^{3}$, Hangeui $\mathrm{Cho}^{2,3 *}$ \\ ${ }^{1}$ Industry-Academic Collaboration Foundation, Seowon University, Cheongju-si, Chungcheongbuk-do, Korea \\ ${ }^{2}$ Department of Cosmetics Engineering, Konkuk University, Seoul, Korea \\ ${ }^{3}$ Creative Innovation Research Center, Cosmecca Korea, Co. Ltd., Seongnam-si, Gyeonggi-do, Korea
}

\author{
*Corresponding author: Hangeui Cho, \\ Creative Innovation Research Center, \\ Cosmecca Korea, Co. Ltd., 6th Floor, \\ ABN Tower, 331 Pangyo-ro, Bundang-gu, \\ Seongnam-si, Gyeonggi-do 13488, Korea \\ Tel.: +82 27846551 \\ Fax: +82 26282290 \\ Email: bioche1975@cosmecca.com
}

Jungwook Kang, Garam Nam and Yeahwa Yoon contributed equally to this work.

Received December 30, 2020

Revised January 25, 2021

Accepted February 2, 2021

Published March 30, 2021

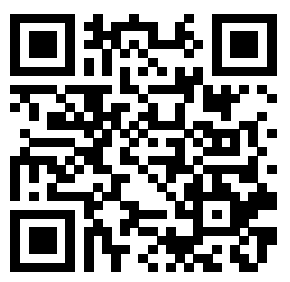

\begin{abstract}
Purpose: This study aims to understand the role Angelica gigas (A. gigas) Nakai root extract (AGNRE) fermented with Jeju lava seawater in collagenase suppression in human dermal fibroblasts, and identify the major active compound responsible for it suppressive effect. Methods: AGNREs were prepared by fermentation with Jeju lava water at low temperature and analyzed for identifying the major active compound in these fermented root extracts using high-performance liquid chromatography (HPLC). Water-soluble tetrazolium salt (WST-1) assay and real-time polymerase chain reaction (qRT-PCR) were performed to investigate the cell viability and expression level of collagenase gene. Comparative experiments were performed using AGNREs and decursin to confirm the downregulation of collagenase expression and analyze the correlation between them. Results: HPLC analysis revealed decursin to be the major active compound in AGNREs. Analysis of data obtained by WST-1 assays at concentration of $200 \mu \mathrm{g} / \mathrm{mL}$ for AGNREs and $<20 \mu \mathrm{M}$ for decursin did not show any cytotoxicity in human dermal fibroblasts. qRT-PCR analysis revealed that AGNREs as well as decursin downregulated the expression of matrix metalloproteinases-3 (MMP3) gene in human dermal fibroblasts. Conclusion: These analyses suggest that AGNREs fermented with Jeju lava water as well as decursin isolated from these extracts hold a great potential to be applied as functional anti-wrinkle agent in cosmetic.
\end{abstract}

Keywords: Angelica gigas Nakai, Decursin, Collagenase, Jeju lava seawater, Dermal fibroblasts

\section{Introduction}

한국에서 서식하는 당귀인 참당귀(Angelica gigas Nakai, $A$. gigas)는 산형과(Umbelliferae) 당귀속(Angelica L.)에 속한다 (Sarker \& Nahar, 2004). 당귀속에는 60종 이상이 속해 있으며 중 국, 일본, 한국과 같은 아시아 국가에서 한약재나 음식 재료로 사용 되었다(Sarker \& Nahar, 2004). 당귀속 식물의 화학적 구성 성분은 광범위하게 연구되었다. Pyranocoumarin계 화합물은 에탄올이나 메탄올로 추출한 참당귀에서 발견되는 주요물질이다(Zhang et al., 2012). Pyronocoumarin계 화합물들 중에서 가장 많은 비율을 차지
하는 decursin은 1960년대에 바디나물(Angelica decursiva Fr. et Sav.)의 뿌리에서 처음으로 분획되었고(Konoshima et al., 1968) 이 후 참당귀에서 분리되었다(Hata \& Sano, 1969). 그 외에도 참당귀 는 decursinol, decursinol angelate 등을 함유하고 있다(Zhang et al., 2012). 참당귀 추출물과 decursin은 항산화, 항암(Choi et al., 2011), 항염증(Son et al., 2009a), 혈액순환 개선(Kim \& Rhyu, 2010; Kim et al., 2009a), 항비만(Hwang et al., 2012) 등의 분야 에서 많은 연구들이 진행되어 왔다(Zhang et al., 2012).

심해수(deep sea water)는 심해 지역의 500-600 m 이상 깊이에 서 끌어올리는 수자원으로, 심해수를 구성하는 다양한 미네랄 성분 


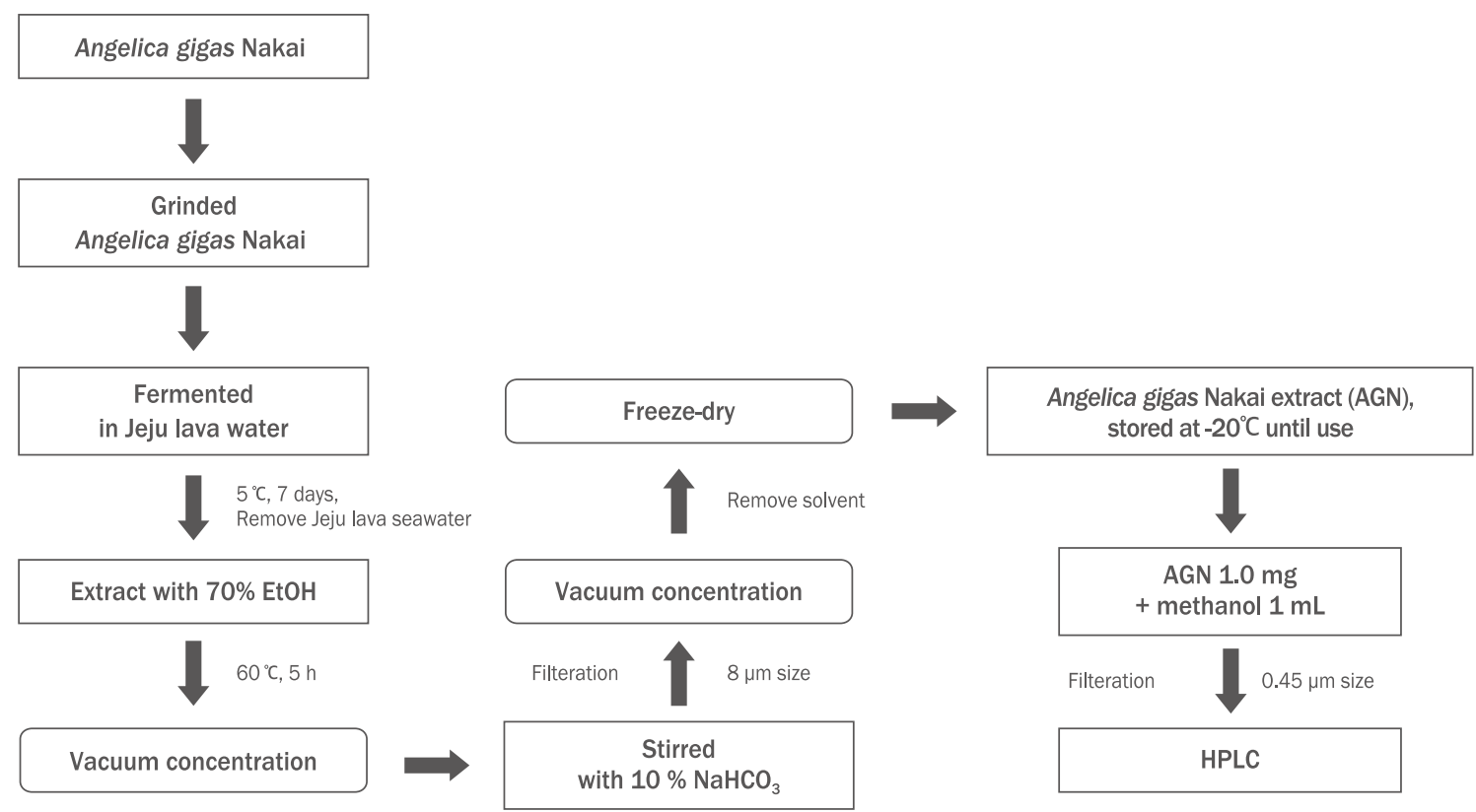

Figure 1. Process of isolating Angelica gigas Nakai root extracts and high-performance liquid chromatography.

Angelica gigas Nakai root was ground and fermented in Jeju lava water at $4{ }^{\circ} \mathrm{C}$. After 14 days, Angelica gigas Nakai root was extracted with $70 \%$ ethanol at $60^{\circ} \mathrm{C}$ for $5 \mathrm{~h}$, concentrated on pressure reduction after adding $10 \% \mathrm{NaHCO}_{3}$ solution, and then stirred at high temperatures. The extract was filtered using a Whatman No. 2 filter paper, and the solvent was removed by decompression. This extract was frozen and stored at $-20^{\circ} \mathrm{C}$.

으로 인해 심혈관 질환, 당뇨병, 비만, 암 증상에 긍정적인 영향을 끼 친다는 연구 보고가 있다(Song et al., 2020). 본 연구에 사용된 제주 용암해수는 심해수와 유사한 광물 성분을 가지는 한편, 약 100-200 $\mathrm{m}$ 의 지하에서 얻어지기에 심해수에 비해 더 경제적으로 이점을 가 진다(Noh et al., 2010; Lee et al., 2019). 제주 용암해수는 제주에 서만 얻을 수 있는 자원으로 화산 암반층에 바닷물이 자연 여과되어 만들어진다. 그로 인해 일반적인 수자원보다 칼슘, 마그네슘, 셀레 늄, 게르마늄 등의 필수 미네랄과 철, 망간, 아연 등의 유용한 미네랄 을 다량으로 함유하고 있다(Bae et al., 2012). 이러한 미네랄 성분을 포함하는 제주 용암해수의 식이 섭취를 통해 항산화, 항염 효능을 보 고한 연구 결과도 존재한다(Kim et al., 2020a). 제주 용암해수는 피 부의 보습 효능 또한 가진다고 알려져 있다(Lee et al., 2016). 각질 형성세포에서 제주 용암해수는 피부 내 천연보습인자 생성을 증가시 키고 수분의 수송과 관련된 막 단백질의 발현 역시 증가시킨다고 보 고되어 있다(Lee et al., 2016). 또한, 제주 용암해수를 처리한 인간 피부 모델에서 각질층의 두께 증가로 인하여 피부장벽능이 강화된 것을 확인할 수 있다(Lee et al., 2016).

피부 노화는 생물학적으로 피할 수 없는 유기체의 과정이며 내 인적 요인과 외인적 요인에 의해 유발된다(Im et al., 2019). 연령 에 따른 노화인 내인성 피부 노화는 인체 내부의 생리적 요인에 의
하여 발생하며, 외인성 노화는 자외선 조사, 흡연, 대기 오염 등 많 은 외부 요인의 영향을 받아 발생한다(Im et al,, 2019). 이러한 요 인들은 주름, 색소 침착 및 피부의 두께 감소를 일으킬 수 있다(Im et al., 2019). 콜라겐은 진피 조직의 탄력과 관련되어 있고, 피부 노 화의 대표적 증상인 주름은 콜라겐 양의 감소로 인해 발생한다(Kim et al., 2016). 성인의 진피층은 콜라겐 타입 I이 80-85\%, 콜라겐 타 입 III이 10-15\%의 비율로 구성되어 있으며, 이 외에도 글리코사미 노글리칸(glycosaminoglycans, GAGs)과 엘라스틴 섬유질이 포함되 어 있다(Baumann et al., 2006). 콜라겐은 피부 탄력과 밀접한 연관 이 있으며 외부 자극에 대항하여 장력을 제공한다. 또한, 피부의 구 조적 골격을 유지하여 피부 형태 유지에 중추적인 역할을 한다(Kim et al., 2016; Jang, 2018). 이러한 콜라겐 타입 I, 타입 III은 진피 섬유아세포에 의해 $\alpha$-프로콜라겐으로 합성된다(Baumann et al., 2006; Ryu et al., 2019). 외부적인 요인에 의한 세포외 기질의 손상 은 광노화의 특징으로, 자외선으로 인한 matrix metalloproteinases (MMPs)의 발현 증가는 콜라겐 손상을 야기하고 이는 광노화로 이 어진다(Baumann et al., 2006; Kim et al., 2018a; Kim et al., 2020b). MMPs는 세포외 기질의 대부분 구성물질들을 분해할 수 있는 효소로(Brennan et al., 2003), collagenases, gelantinases, stromelysins, matrilysins, membrane-type MMPs로 구분된 
다(Philips et al., 2011). 콜라겐분해효소(collagenase)에 속하는 $\mathrm{MMP1}, \mathrm{MMP} 8, \mathrm{MMP} 13$ 은 콜라겐 타입 I, 타입 III의 분해에 관여 하며, MMP1이 가장 주요하게 콜라겐을 분해한다(Brennan et al., 2003; Kim et al., 2018b). Stromelysins 중 하나인 MMP3은 광범 위하게 콜라겐을 포함한 세포외 기질의 단백질들(프로테오글리칸, 기저막 콜라겐, 매트릭스 당 단백질)을 분해하는 효소이다(Philips et al., 2011). 따라서 피부의 주름을 개선하기 위해서는 MMP3와 같은 콜라겐분해효소의 발현 및 생합성을 조절하는 것이 중요하다(Kim et al., 2016).

본 연구에서 고성능 액체 크로마토그래피를 통해 참당귀 뿌리 추 출물 내의 주요 지표 성분으로서 decursin의 함유율을 확인하였다. 또한 decursin의 콜라겐분해효소 발현 감소 효과와 그에 따른 참당 귀 뿌리 추출물의 콜라겐분해효소 발현 감소 효과를 실험적으로 증 명하였다. 이를 통해 참당귀 뿌리 추출물에 의한 콜라겐분해효소 발 현 변화를 확인하고 나아가 참당귀 뿌리 추출물 및 decursin의 새로 운 주름개선용 기능성화장품 원료로서의 가능성을 제시하고자 한다.

\section{Methods}

\section{1. 참당귀 뿌리 추출물의 제조}

참당귀 뿌리 추출물 제조에 사용된 참당귀는 충북 제천에서 수집 및 가공한 참당귀를 구입((주)토종마을, Korea)하여 사용하였다. 참 당귀 뿌리를 분쇄한 시료 중량의 10 배의 양으로 제주 용암해수(제 주테크노파크 용암해수센터, Jeju, Korea)를 넣어 침지시킨 후, $5^{\circ} \mathrm{C}$ 에서 7일간 저온 숙성하였다. 그 후 제주 용암해수를 제거한 시료 에 $70 \%$ 에탄올을 넣고 $60^{\circ} \mathrm{C}$ 에서 $5 \mathrm{~h}$ 동안 가온 추출 후, 감압 농축 (EYELA; Rotary evaporator, Japan)하여 얻어진 수득물에 $10 \%$ $\mathrm{NaHCO}_{3}$ 수용액을 넣고 고온에서 교반하였다. 추출물은 여과지 (Whatman No. 2; All for LAB, Korea)를 이용하여 여과한 후 감압 농축하여 용매를 제거하였다. 이후 동결 건조하여 $-20^{\circ} \mathrm{C}$ 에 보관하
여 본 실험의 시료로 사용하였다(Figure 1).

\section{2. 고성능 액체 크로마토그래피를 통한 지표물질 탐색}

참당귀 뿌리 추출물에서 단일물질인 decursin의 함유 여부를 확 인하기 위하여 고성능 액체 크로마토그래피 분석방법을 사용하였다. 표준 용액은 decursin 표준물질(SML0786; Sigma-Aldrich, USA) $1.0 \mathrm{mg}$ 을 정밀 측정하여 $85 \%$ methanol $1 \mathrm{~mL}$ 을 이용하여 녹인 후, PVDF 0. $45 \mu \mathrm{m}$ 필터(Whatman $\mathrm{GmbH}$, Germany)로 여과하여 표 준용액으로 하였다 $(1000 \mu \mathrm{g} / \mathrm{mL})$. 시험 용액의 경우, 참당귀 뿌리 추출물 $10.0 \mathrm{mg}$ 을 정밀하게 측정해 이를 $85 \%$ methanol $10 \mathrm{~mL}$ 을 이용하여 녹인 후 PVDF $0.45 \mu \mathrm{m}$ 필터로 여과하여 제조하였다(1.0 mg/mL). 이후 Alliance 2695 HPLC-PDA (2996) System (Waters Corp., USA)을 이용하여 컬럼 온도 $30^{\circ} \mathrm{C}$, 주입량 $10 \mu \mathrm{L}$, 이동속도 분 당 $1.0 \mathrm{~mL}$ 의 조건으로 분석하였다. 이후, 특이성, 정확성, 정밀 성 시험을 통해 분석법의 유효성을 검증하였다.

\section{3. 세포주 배양}

본 연구에서 사용된 인간 진피섬유아세포(Human BJ-tert fibroblasts)는 American Type Culture Collection (ATCC, USA)에 서 동결상태로 구입한 Human BJ fibroblasts를 tert-immortalized 하여 사용하였다. 인간 진피섬유아세포는 $10 \%$ fetal bovine serum (FBS; Biowest, France)을 포함시킨 high glucose Dulbecco's modified eagle medium (DMEM; Biowest)배지를 사용하였고, 그 외에 인산완충생리식염수(phosphate-buffered saline, PBS; Welgene, Korea)와 $37^{\circ} \mathrm{C}, 5 \% \mathrm{CO}_{2}$ 의 조건으로 세포배양기(Thermo Fisher Scientific, USA)에서 배양하였다.

\section{4. 세포 생존율 측정}

참당귀 뿌리 추출물과 decursin의 세포 독성 측정은 watersoluble tetrazolium salt (WST-1) assay (EZ-cytox cell viability kit; ITSBio, Korea) 법을 통해 진행하였다. Human BJ-tert

Table 1. List of primers for real-time polymerase chain reaction (qRT-PCR)

\begin{tabular}{lll}
\hline Gene & Sequence $\left(5^{\prime}\right.$ to $\left.3^{\prime}\right)$ & \\
\multirow{2}{*}{ COL1A1 } & Forward & GAGAGCATGACCGATGGATT \\
& Reverse & CCTTCTTGAGGTTGCCAGTC \\
& Forward & GGGCTTGAAGCTGCTTACGA \\
MMP3 & Reverse & ACAGCCCAGTACTTATTCCCTTTG \\
& Forward & ATGCCCACTTTGATGATGATGAAC \\
GAPDH & Reverse & CCACGCCTGAAGGAAGAGATG \\
& Forward & GTCTCCTCTGACTTCAACAGCG \\
\hline
\end{tabular}

COL1A1, collagen type I alpha 1 chain; MMP1, matrix metallopeptidase 1; MMP3, matrix metallopeptidase 3; GAPDH, glyceraldehyde-3phosphate dehydrogenase. 
A

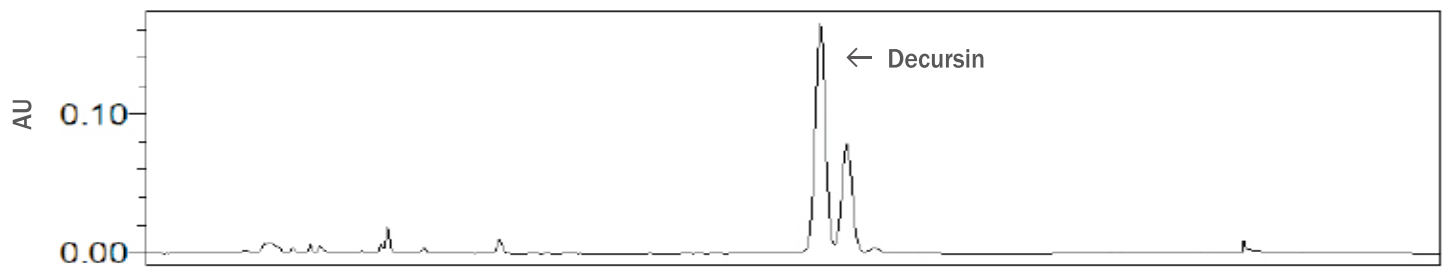

B

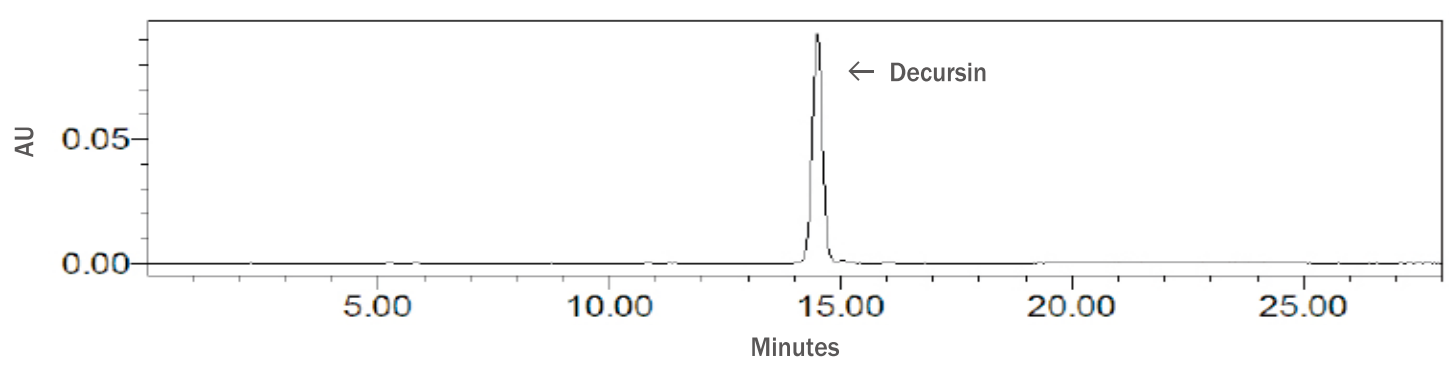

C<smiles>CC(C)=CC(=O)O[C@H]1Cc2cc3ccc(=O)oc3cc2OC1(C)C</smiles>

Figure 2. HPLC analysis of Angelica gigas Nakai root extracts and the chemical structure of decursin.

(A) HPLC chromatogram (254 nm) of a test solution ( $250 \mu \mathrm{g} / \mathrm{mL}$; diluted standard solution); (B) HPLC chromatogram (254 $\mathrm{nm}$ ) of a test solution for the preparation of linearity (dimension line); (C) The chemical structure of decursin.

fibroblasts를 96 well plate에 각 well당 $3.0 \times 10^{3}$ cells씩 분주하여 세포배양기에서 24 시간 배양하였다. 이후, 참당귀 뿌리 추출물은 $0,10,20,50,100,200,500 \mu \mathrm{g} / \mathrm{mL}$ 로, decursin은 $0,2,5,10$, $20,50,100 \mu \mathrm{M}$ 로 각각 처리하여 세포배양기에 배양하였다. 24 시 간 후, WST-1 solution을 처리하여 반응시킨 후, iMark Microplate Absorbance Reader (\#1681130; Bio-Rad, USA)를 이용하여 450 $\mathrm{nm}$ 에서 흡광도를 측정하였다. Reference 흡광도는 $650 \mathrm{~nm}$ 에서 측 정하여 결과값을 도출하였다.

\section{5. qRT-PCR을 이용한 유전자 발현 분석}

진피 섬유아세포에서 참당귀 뿌리 추출물과 decursin 처리에 따른 콜라겐 및 콜라겐분해효소의 발현 변화를 정량적으로 확인하기 위해 $\mathrm{qRT}-\mathrm{PCR}$ 을 이용하여 mRNA 발현 분석을 진행하였다. COL1A1, $M M P 1, M M P 3$ 의 발현을 확인하는 실험의 양성대조군으로는 transforming growth factor-beta (TGF- $\beta$; Sigma-Aldrich) 5 $\mathrm{ng} / \mathrm{mL}$ 를 사용하였으며, $-80^{\circ} \mathrm{C}$ 에서 보관하였다. Human BJ-tert fibroblasts에 시료를 처리한 후, Ribo ex TM total RNA isolation solution (GeneAll Biotechnology, Korea)와 scraper를 이용하여 세 포를 용해하였다. 이 용액에 클로로포름(Sigma-Aldrich)을 Ribo ex 용액의 $1 / 5$ 의 양만큼 넣어 원심 분리 $\left(12000 \mathrm{rpm}, 4^{\circ} \mathrm{C}\right)$ 하였다. 이후 RNA가 있는 상층액을 분리하여 아이소프로판올(Merckmillipore,
Germany)을 상층액과 동량 넣어 inverting 후 원심분리(12000 $\left.\mathrm{rpm}, 4^{\circ} \mathrm{C}\right)$ 하였다. $\mathrm{RNA}$ 를 침전시켜 침전물을 제외한 상층액은 버 리고 남아있는 침전물에 $70 \%$ 에탄올(Merckmillipore)을 넣어 원 심 분리 $\left(12000 \mathrm{rpm}, 4^{\circ} \mathrm{C}\right)$ 하여 세척하였다. 이후, 에탄올을 제거하 고 nuclease free water (Affymetrix, USA)로 용해하여 total RNA 를 추출하였다. MaestroNano Micro-volume Spectrophotometer (MN-913; Maestrogen, USA)를 이용하여 A260/A280 파장에 서 RNA의 순도와 농도를 측정한 뒤, $260 \mathrm{~nm}$ 와 $280 \mathrm{~nm}$ 의 비가 약 2.2 임을 확인하였다. M-MLV reverse transcriptase (Invitrogen, USA)와 oligo dT (Bionics, Korea), dNTP (Takara, Japan)를 사 용하여 complementary DNA (cDNA)를 합성하였다. $\mathrm{qRT}-\mathrm{PCR}$ 은 denaturation $\left(95^{\circ} \mathrm{C}, 15 \mathrm{~min}\right)$ 후 denaturation $\left(95^{\circ} \mathrm{C}, 15 \mathrm{~s}\right)$, annealing $\left(60^{\circ} \mathrm{C}, 30 \mathrm{~s}\right)$, polymerization $\left(72^{\circ} \mathrm{C}, 30 \mathrm{~s}\right)$ 과정을 40 cycles 반복하여 반응시켜 측정하였다. 유전자의 threshold cycle $(\mathrm{Ct})$ 값을 $\mathrm{GAPDH}$ 발현에 대한 $\mathrm{Ct}$ 값으로 표준화한 후, $\mathrm{Ct}$ 값의 변화 량을 비교하여 상대적인 유전자의 발현 정도를 정량 분석하였다. 실 험에 사용했던 유전자 primer 정보는 Table 1과 같다.

\section{6. 통계분석}

모든 실험은 독립적으로 3 회 반복하여 진행하였고, 통계분석 데이 터는 평균값 \pm 표준편차(Mean \pm Standard Deviation, $\mathrm{SD})$ 로 나타내 
A

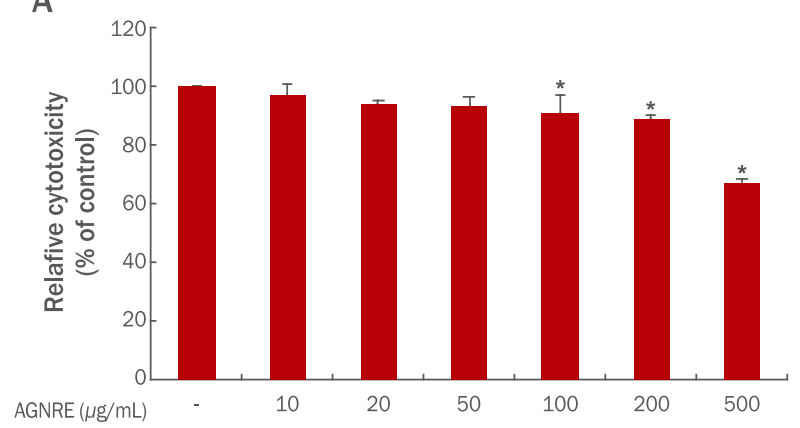

B

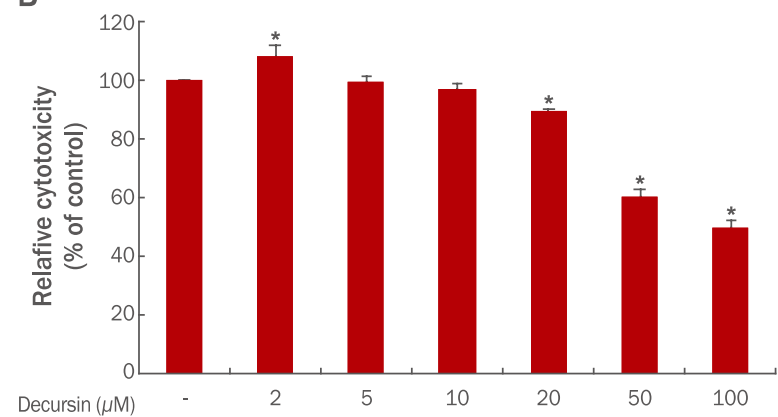

Figure 3. The cell viability assay for analyzing the effect of Angelica gigas Nakai root extracts and decursin on human dermal fibroblasts.

Human BJ-tert fibroblasts $\left(3 \times 10^{3}\right)$ were seeded and treated with indicated doses of the: (A) Angelica gigas Nakai root extracts and (B) decursin for $24 \mathrm{~h}$ separately. WST-1 assay was conducted to evaluate the cell viability. Each bar represents the mean \pm S.D. from three independent experiments. AGNRE, Angelica gigas Nakai root extract; TGF- $\beta$, transforming growth factor-beta. ${ }^{*} p<0.05$ indicates statistical significance.

었다. 데이터 통계처리를 위해 Student's $t$-test 분석(양측분석, 등 분산 조건)을 이용하였다. 이를 통해 구한 ${ }^{*} p$-value 값이 0.05 미만 인 경우 통계적으로 유의하다고 판정하였다.

\section{Results and Discussion}

\section{1. 제주 용암해수 저온추출법으로 추출한 참당귀 추출물 내 지표 성분 분석}

제주 용암해수는 제주 지형의 특성을 이용하여 얻어지며, 다른 지 하해수에 비해 경제적이고 당뇨, 심장질환, 비만 등의 증상 완화에 도움이 되는 많은 미네랄을 함유하고 있어 이로운 천연자원으로 각 광받고 있다(Noh et al., 2010). 이러한 제주 용암해수로 저온에서 숙성하여 추출한 참당귀 뿌리 추출물을 본 연구에 사용하였다.

참당귀 뿌리 추출물(Sample 20190810, Sample 20190908, Sample 20190927) 내 지표물질을 분석하기 위해 고성능 액체 크로 마토그래피 실험법을 사용하였다. 분석 결과, 참당귀 뿌리 추출물 내에서 주요한 peak 2 개가 검출되었으며, 이는 decursin의 표준용 액 $(250 \mu \mathrm{g} / \mathrm{mL}$ 로 희석)의 peak와 동일함이 확인되었다(Figure $2 \mathrm{~A}$, 2B).

분석법의 유효성을 검증하기 위하여 특이성 시험, 정확성 시 험, 정밀성 시험을 수행하였고 참당귀 뿌리 추출물의 지표성분인 decursin 정량에 대한 유효성 검증이 올바르게 수행되었음을 확인하 였다. 3개의 로트의 참당귀 뿌리 추출물(Sample 20190810, Sample 20190908, Sample 20190927)의 decursin 함량을 측정한 결과 최 저 함량은 $441.32 \mathrm{mg} / \mathrm{g}$, 최고 함량은 $457.67 \mathrm{mg} / \mathrm{g}$ 로 확인되었으 며, 평균 함량은 $451.22 \mathrm{mg} / \mathrm{g}$ 이었다(data not shown).

Decursin은 pyranocoumarin 구조를 기본으로 한 유도체이다.
Decursin은 decursinol의 $\mathrm{OH}$ 기 대신에 senecioylic acid가 치환되어 있는 3-methyl-but-2-enoic acid 2,2-dimethyl-8-oxo-3,4dihydro- $2 \mathrm{H}, 8 \mathrm{H}$-pyrano[3,2-g]chromen-3-yl ester이다. 분자 식은 $\mathrm{C}_{19} \mathrm{H}_{20} \mathrm{O}_{5}$, 분자량은 $328.36 \mathrm{~g} / \mathrm{mol}$ 로서 decursinol angelate 와 구조 이성질체이다(Figure 2C). Decursin의 규명된 약리 효과로 는 종양 억제, 박테리아 성장 억제, 순환계 질환 개선, 대사 효소 억 제, 항염증, 항산화, 인지 개선 효과 등이 있다(Son et al., 2009b). Decursin과 같은 쿠마린 성분은 강력한 잔틴산화효소 억제 효과가 있다(Chang \& Chiang, 1995)는 연구보고가 있기에, 이미 알려진 약리 효과들 외에도 보고되지 않은 다양한 효능이 존재할 것으로 생 각된다.

\section{2. 참당귀 뿌리 추출물과 decursin의 세포 독성(cytotoxicity) 평가}

인간 진피섬유아세포는 세포외 기질과 콜라겐을 합성하는 세포의 일종으로, 상피세포 분화 조절, 염증 조절, 조직 손상에 대한 면역 반 응 등의 기능을 한다. 추가적으로, 상처 치유에도 중요한 역할을 한 다(Kalluri \& Zeisberg, 2006).

참당귀 뿌리 추출물과 decursin에 대한 인간 진피섬유아세포 내 콜라겐 및 콜라겐분해효소 발현 변화를 확인하기에 앞서, 세포에 처리했을 때 나타나는 세포 독성도 및 독성 유발 농도를 확인하였 다. Human BJ-tert fibroblasts를 대상으로 참당귀 뿌리 추출물과 decursin을 각각 0, 10, 20, 50, 100, 200, $500 \mu \mathrm{g} / \mathrm{mL}, 0,2,5,10$, $20,50,100 \mu \mathrm{M}$ 의 농도로 $24 \mathrm{~h}$ 처리한 후, WST-1 assay를 통하 여 세포 생존율을 분석하였다. 참당귀 뿌리 추출물을 처리하는 경우 $200 \mu \mathrm{g} / \mathrm{mL}$ 의 농도에서 $87.2 \pm 6.1 \%$ 의 세포 생존율을 보였다. 그 미 만의 농도에서는 $90 \%$ 이상의 생존율을 보이며 세포 독성이 나타나 지 않았다(Table 2A, Figure 3A). Decursin의 경우, $20 \mu \mathrm{M}$ 의 농도 에서 $89.7 \pm 2.2 \%$ 의 세포 생존율을 보였다. 그 미만의 농도에서 $90 \%$ 
A
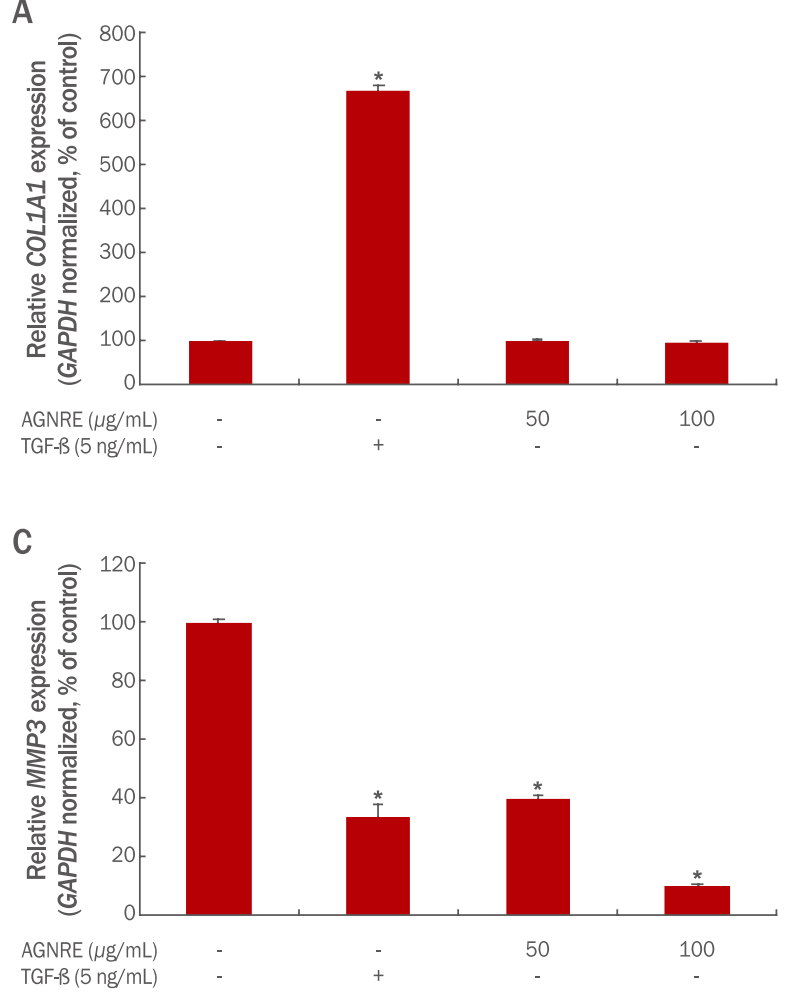

B

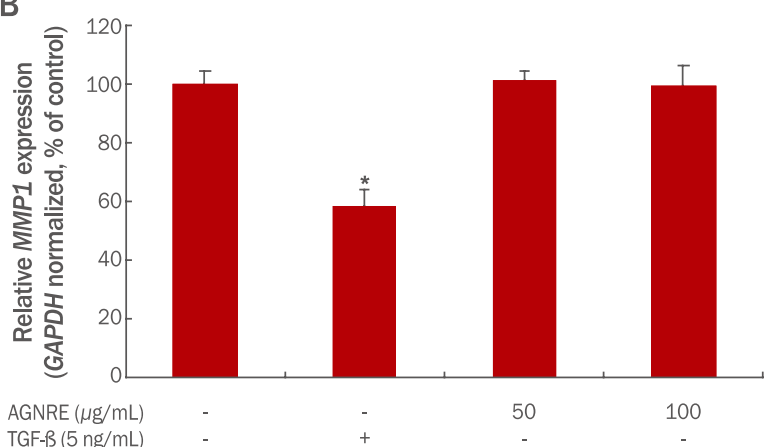

D

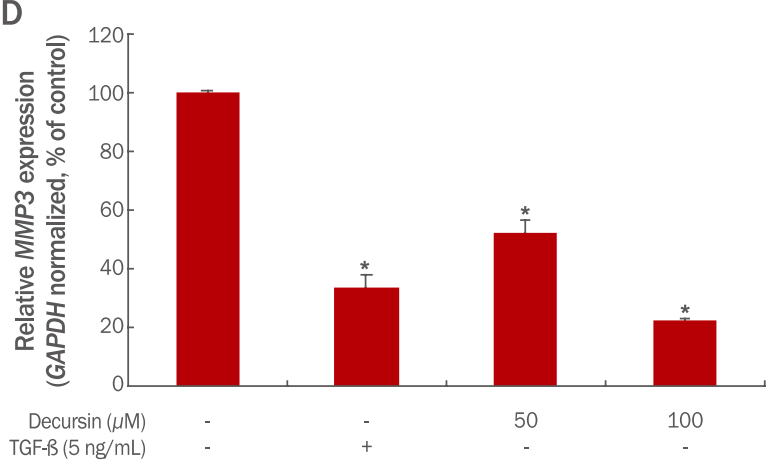

Figure 4. Effects of Angelica gigas Nakai root extracts and decursin on the expression of $M M P 3$ in human dermal fibroblasts.

Human BJ-tert fibroblasts $\left(2 \times 10^{5}\right)$ were seeded in $60 \mathrm{~mm}$ culture dish and treated with the indicated doses of the AGNREs and decursin for 24 hours separately. The expression levels of COIA1, MMP1, and MMP3 in cells treated with AGNREs and MMP3 levels in cells treated with decursin were analyzed using qRT-PCR experiments. The expression level of (A) COL1A1 in AGNREs-treated human BJ-tert fibroblasts and (B) MMP1 in AGNREs-treated human BJ-tert fibroblasts, Dose-dependent downregulation of MMP3 expression in (C) AGNREs-treated human BJ-tert fibroblasts and (D) decursin-treated human BJ-tert fibroblasts. TGF- $\beta$ was used as the positive control. Each bar represents the mean $\pm S$.D. from three independent experiments. AGNREs, Angelica gigas Nakai root extracts; TGF- $\beta$, transforming growth factorbeta. ${ }^{*} p<0.05$ indicates statistical significance. COL1A1, collagen type I alpha 1 chain; MMP1, matrix metallopeptidase 1; MMP3, matrix metallopeptidase 3; GAPDH, glyceraldehyde-3-phosphate dehydrogenase.

이상의 생존율로 세포 독성이 나타나지 않았다(Table $2 \mathrm{~B}$, Figure $3 \mathrm{~B})$. 본 실험 결과를 바탕으로, 이후 실험에 있어서는 세포 처리 농 도를 참당귀 뿌리 추출물은 $0,50,100 \mu \mathrm{g} / \mathrm{mL}$, decursin은 $0,5,10$ $\mu \mathrm{M}$ 으로 하여 진행하였다.

\section{3. 참당귀 뿌리 추출물과 decursin의 collagen ( $C O L 1 A 1)$,} collagenase (MMP1, MMP3) 발현 조절능 평가

콜라겐은 결합 조직의 주성분으로서 강한 신장력을 가져 쉽게 분 해되지 않는 특징을 가지지만, 자외선 조사, 연령 증가 등의 여러 요 인에 의해 분해가 촉진된다. 그리고 콜라겐분해효소는 콜라겐을 구 성하는 결합을 분해하여 결론적으로 콜라겐의 합성을 저해한다(Kim et al., 2009b). 이렇듯 피부의 탄력을 유지시켜주는 역할을 하는 콜 라겐이 콜라겐분해효소의 발현량 증가에 따라 분해되어 노화에 의 한 피부 주름 생성의 원인이 된다는 여러 보고가 있다(Sansilvestri-
Morel et al., 2005). 본 연구에서는 qRT-PCR 측정법을 통해 참당 귀 뿌리 추출물과 decursin에 의한 dermal fibroblasts에서의 콜라겐 및 콜라겐분해효소 발현량을 평가하였다. 본 실험의 양성대조군으로 는 $\mathrm{TGF}-\beta 5 \mathrm{ng} / \mathrm{mL}$ 를 사용하였으며, $-80^{\circ} \mathrm{C}$ 에서 보관하였다.

참당귀 뿌리 추출물을 human BJ-tert fibroblasts에 0, 50, 100 $\mu \mathrm{g} / \mathrm{mL}$ 의 농도로 24 시간 처리한 후, Table 1 에서 언급한 primer 를 사용하여 $\mathrm{qRT}-\mathrm{PCR}$ 분석법을 통해 COL1A1과 $M M P 1, M M P 3$ 의 발현 증감 유무를 확인하였다. 참당귀 뿌리 추출물을 처리한 세 포 내 COL1A1 및 MMP1 발현에서는 유의한 증감이 나타나지 않 았다(Figure $4 \mathrm{~A}, 4 \mathrm{~B})$. 반면, 참당귀 뿌리 추출물을 처리한 세포 내 $\mathrm{MMP} 3$ 발현을 확인한 결과, 농도의존적으로 현저히 감소하는 경향 을 보였다. $50 \mu \mathrm{g} / \mathrm{mL}, 100 \mu \mathrm{g} / \mathrm{mL}$ 참당귀 뿌리 추출물이 처리된 세 포에서는 $M M P 3$ 발현이 대조군 대비 $39.3 \pm 4.5 \%, 9.6 \pm 0.8 \%$ 로 감 소하였다(Table 3 , Figure $4 \mathrm{C}$ ). 본 실험을 통해 참당귀 뿌리 추출물 
이 인간 진피섬유아세포 내 $C O L 1 A 1$ 과 $M M P 1$ 발현 변화에 관여하 지 않음을 알 수 있었다. 하지만 $M M P 3$ 발현이 현저히 감소하였다. 당귀를 초임계 추출 시 콜라겐 합성과 연관이 있는 단백질의 발현에 의해 항노화 효능이 나타난다고 보고되었다(Yoo et al., 2011). 본 연 구에서는 제주 용암해수로 추출한 참당귀 뿌리 추출물이 인간 진피 섬유아세포에서 $M M P 3$ 발현 억제를 통해 피부의 주름 개선 소재로 서의 가능성이 있음을 확인하였다.

상기 결과를 바탕으로 참당귀 뿌리 추출물에 의한 인간 진피섬유 아세포 내 $M M P 3$ 발현 억제 효과가 참당귀 뿌리 추출물 내 지표 물 질인 decursin에 의한 것인지 분석하였다. Decursin을 human BJtert fibroblasts에 $0,5,10 \mu \mathrm{g} / \mathrm{mL}$ 의 농도로 24 시간 처리한 후. $M M P 3$ 발현 변화를 $\mathrm{qRT}-\mathrm{PCR}$ 분석법을 통해 확인하였다. 그 결과, decursin을 처리한 세포 내 $M M P 3$ 발현이 농도의존적으로 현저하 게 감소하는 경향을 보였다. $5,10 \mu \mathrm{M}$ decursin이 처리된 세포에서 $M M P 3$ 발현이 대조군 대비 $52.3 \pm 8.7 \%, 22.1 \pm 2.5 \%$ 로 감소하였다 (Figure $4 \mathrm{D})$. 따라서 본 실험 결과를 바탕으로, 참당귀 뿌리 추출물 에 의한 인간 진피섬유아세포 내 콜라겐분해효소 발현 감소 효능은 decursin에 의해서 나타날 수 있음을 확인하였다.

다양한 세포 기질의 분해를 담당하는 $M M P 3$ 의 발현 억제는 콜라 겐분해효소 중 하나인 pro- $M M P 1$ 를 활성화하여 주름 생성에 영향 을 미치는 것으로 보고되었다(Yao et al., 2015). 본 연구에서는 콜라 겐 분해효소 중 하나인 $M M P 3$ 발현 억제를 확인함으로 주름개선 효 과의 지표물질로 가능성을 확인하였다. 인간 진피섬유아세포 내에서 참당귀 뿌리 추출물의 콜라겐 유전자의 발현 증가는 확인할 수 없었 으나 콜라겐분해효소 중 한 종류인 $M M P 3$ 발현이 감소하였기 때문 에, 참당귀 뿌리 추출물이 콜라겐 분해를 저해한다는 것을 알 수 있 었다. 또한 decursin으로 인해 $M M P 3$ 발현이 감소되었기 때문에 참 당귀 뿌리 추출물의 인간 진피섬유아세포 내 콜라겐분해효소의 발현 감소 효과가 지표물질인 decursin에 의한 것일 가능성도 확인하였 다.

육안 상으로 확인할 수 있는 노화의 대표적인 현상인 주름은 콜라 겐 발현 감소와 MMPs 발현 증가에 따른 콜라겐 분해 증가에 기인한 것이다(Sjerobabski-Masnec \& Šitum, 2010). 따라서 참당귀 뿌리 추출물과 decursin이 주름 개선 효능이 있음을 확인하였다.

\section{Conclusion}

참당귀(A. gigas Nakai)는 오래전부터 한약재로서 사용되었던 천 연물이기에 보고된 약리 효과가 많고 그에 따른 특허도 많다. 이는 많은 사람들이 참당귀에서 의약품, 화장품의 소재로의 개발 가능성 을 알아봤다는 뜻으로도 해석된다. 본 연구에서는 참당귀 뿌리 추출 물의 주름 개선용 화장품 기능성 소재로서의 가치를 확인하고자 인 간 진피섬유아세포 내 콜라겐과 콜라겐분해효소 발현 변화를 측정하
였다. 먼저 참당귀 뿌리 추출물의 콜라겐 $(C O L 1 A 1)$ 발현 변화를 측 정하여 분석하였지만 유의한 증감이 나타나지 않았다. 이어서 콜라 겐분해효소인 $M M P 1, M M P 3$ 발현 변화를 측정하여 분석하였다. 그 결과, $M M P 1$ 에 대한 유의한 발현 변화는 없었으나 $M M P 3$ 의 발현이 감소되었다. 따라서 참당귀 뿌리 추출물이 진피 섬유아세포 내에서 $M M P 3$ 발현이 감소시킨다는 것을 확인하였다.

참당귀 뿌리 추출물의 효능에 대한 지표물질을 확인하고자 고성능 액체 크로마토그래피 분석을 진행하였다. 고성능 액체 크로마토그래 피를 통해 decursin이 참당귀 뿌리 추출물의 주요한 단일 물질이며, 높은 함량으로 존재함을 확인하였다. 참당귀 뿌리 추출물 처리 후 $M M P 3$ 에 대한 발현 감소 효능이 decursin에 의한 것임을 확인하기 위해 human BJ-tert cell에 decursin을 처리하였다. qRT-PCR을 통한 측정 실험으로 decursin이 인간 진피섬유아세포 내 콜라겐분해 효소 발현량을 감소시키는 효능이 있음을 검증하였다. 따라서 해당 결과를 바탕으로 참당귀 뿌리 추출물과 decursin은 콜라겐분해효소 발현 감소 효과가 우수한 것을 확인할 수 있었으며, 참당귀 뿌리 추 출물 및 decursin의 피부 주름 개선에 대한 신규 화장품 물질로서의 가능성을 확인하였다.

\section{Acknowledgements}

본 연구는 중소벤처기업부와 산업통상자원부가 지원하는 월드 클래스 300 프로젝트 R\&D (S2525362) 지원사업을 통해 수행된 연구결과이며, 이에 감사드립니다.

\section{Author's contribution}

JK, GN, YY, GK, SWB and HL performed experiments and JK, GN, YY, GK, SWB, HL, SHB, YC and HEC analyzed the data. JK, GN, YY, HDC and HEC designed overall experiments together and JK, GN, YY and HEC wrote the manuscript. All authors read and confirmed the final version of manuscript.

\section{Author details}

Jungwook Kang (Assistant Professor), IndustryAcademic Collaboration Foundation, Seowon University, 377-3 Musimseoro, Seowon-gu, Cheongju-si, Chungcheongbuk-do 28674, Korea; Garam Nam (Graduate Student), Department of Cosmetics Engineering, Konkuk University, 120 Neungdong-ro, Gwangjingu, Seoul 05029, Korea); Yeahwa Yoon (Graduate Student), Department of Cosmetics Engineering, Konkuk University, 120 Neungdong-ro, Gwangjin-gu, Seoul 05029, Korea); Gyeongmi Kim (Graduate Student), Department of Cosmetics Engineering, Konkuk University, 
120 Neungdong-ro, Gwangjin-gu, Seoul 05029, Korea; Sowon Bae (Graduate Student), Department of Cosmetics Engineering, Konkuk University, 120 Neungdongro, Gwangjin-gu, Seoul 05029, Korea; Hyunjeong Lee (Graduate Student), Department of Cosmetics Engineering, Konkuk University, 120 Neungdong-ro, Gwangjin-gu, Seoul 05029, Korea); Seunghee Bae (Assistant Professor), Department of Cosmetics Engineering, Konkuk University, 120 Neungdong-ro, Gwangjin-gu, Seoul 05029, Korea; Youngkwon Cha (Director), Creative Innovation Research Center, Cosmecca Korea, Co. Ltd., 6th Floor, ABN Tower, 331 Pangyo-ro, Bundang-gu, Seongnam-si, Gyeonggi-do 13488, Korea; Hyundae Cho (Executive Director), Creative Innovation Research Center, Cosmecca Korea, Co. Ltd, 6th Floor, ABN Tower, 331 Pangyo-ro, Bundang-gu, Seongnam-si, Gyeonggi-do 13488, Korea; Hangeui Cho (Research Fellow), Creative Innovation Research Center, Cosmecca Korea, Co. Ltd., 6th Floor, ABN Tower, 331 Pangyo-ro, Bundang-gu, Seongnam-si, Gyeonggi-do 13488, Korea.

\section{References}

Bae KH, Kim KJ, Kim NY, Song JM. In vitro culture of rare plant Bletilla striata using Jeju magma seawater. Journal of Plant Biotechnology, 39: 281-287, 2012.

Baumann L, Kaufman J, Saghari S. Collagen fillers. Dermatologic therapy, 19: 134-140, 2006.

Brennan M, Bhatti H, Nerusu KC, Bhagavathula N, Kang S, Fisher GJ, Varani J, Voorhees JJ. Matrix metalloproteinase-1 is the major collagenolytic enzyme responsible for collagen damage in UV-irradiated human skin. Photochemistry and Photobiology, 78: 43-48, 2003.

Chang WS, Chiang HC. Structure-activity relationship of coumarins in xanthine oxidase inhibition. Anticancer Research, 15: 1969-1973, 1995.

Choi SR, Lee JH, Kim JY, Park KW, Jeong IY, Shim KH, Lee $\mathrm{MK}$, Seo KI. Decursin from Angelica gigas Nakai induces apoptosis in RC-58T/h/SA\# 4 primary human prostate cancer cells via a mitochondria-related caspase pathway. Food and Chemical Toxicology, 49: 2517-2523, 2011.

Hata K, Sano K. Studies on coumarins from the root of
Angelica decursiva FR. et SAV. I. The structure of decursin and decursidin. Journal of the Pharmaceutical Society of Japan, 89: 549-557, 1969.

Hwang JT, Kim SH, Hur HJ, Kim HJ, Park JH, Sung MJ, Yang HJ, Ryu SY, Kim YS, Cha MR. Decursin, an active compound isolated from Angelica gigas, inhibits fat accumulation, reduces adipocytokine secretion and improves glucose tolerance in mice fed a high-fat diet. Phytotherapy Research, 26: 633-638, 2012.

Im KH, Baek SA, Choi J, Lee TS. Antioxidant, anti-melanogenic and anti-wrinkle effects of Phellinus vaninii. Mycobiology, 47: 494-505, 2019.

Jang $\mathrm{HH}$. Effects of acetyl glutamine on the improvement of skin barrier and inhibition of senescence. Asian Journal of Beauty and Cosmetology, 16: 579-589, 2018.

Kalluri R, Zeisberg M. Fibroblasts in cancer. Nature Reviews Cancer, 6: 392-401, 2006.

Kim EY, Rhyu MR. Synergistic vasorelaxant and antihypertensive effects of Ligusticum wallichii and Angelica gigas. Journal of Ethnopharmacology, 130: 545-551, 2010.

Kim CG, Lee DG, Oh J, Lee YH, Lee YJ, Song PH, Song CH, Ku SK. Effects of balneotherapy in Jeju magma-seawater on knee Osteoarthritis model. Scientific Reports, 10: 1-14, $2020 a$.

Kim GY, Lee SJ, Jeon MJ, Kim BM, Kim GT, Kang SM, Lee KY, Shin EJ, Kim SY, Kim YM. Anti-wrinkle and skin turnover improvement effects of niacinamide-dipeptide convergence. Asian Journal of Beauty and Cosmetology, 16: 243-254, 2018a.

Kim HY, Choi HM, Kim SG, Woo SO, Moon HJ, Han SM. Skin health improving effects of Korean freeze-dried royal jelly in human keratinocytes. Asian Journal of Beauty and Cosmetology, 18: 413-422, $2020 b$.

Kim JH, Kim JH, Lee YM, Ahn EM, Kim KW, Yu YS. Decursin inhibits retinal neovascularization via suppression of VEGFR-2 activation. Molecular Vision, 15: 1868-1875, 2009a.

Kim JY, Bae S, Jung J, An S, An IS, Kim YS. Effects of Coptis chinensis extracts on matrix metalloproteinase-1 suppression through JNK/AP-1 axis in human dermal fibroblasts. Asian Journal of Beauty and Cosmetology, 16: 427-435, 2018b.

Kim WS, Park BS, Park SH, Kim HK, Sung JH. Antiwrinkle effect of adipose-derived stem cell: activation of dermal 
fibroblast by secretory factors. Journal of Dermatological Science, 53: 96-102, 2009b.

Kim YM, Jung HJ, Choi JS, Nam TJ. Anti-wrinkle effects of a tuna heart $\mathrm{H}_{2} \mathrm{O}$ fraction on $\mathrm{Hs} 27$ human fibroblasts. International Journal of Molecular Medicine, 37: 92-98, 2016.

Konoshima M, Chi HJ, Hata K. Coumarins from the root of Angelica gigas Nakai. Chemical and Pharmaceutical Bulletin, 16: 1139-1140, 1968.

Lee H, Suh IS, Woo M, Kim MJ, Jung YH, Song YO. Beneficial effects of desalinated magma seawater in ameliorating thioacetamide-induced chronic hepatotoxicity. Biotechnology and Bioprocess Engineering, 24: 126134, 2019.

Lee SH, Bae IH, Min DJ, Kim HJ, Park NH, Choi JH, Shin JS, Kim EJ, Lee HK. Skin hydration effect of Jeju lava sea water. Journal of the Society of Cosmetic Scientists of Korea, 42: 343-349, 2016.

Noh JR, Gang GT, Kim YH, Yang KJ, Lee CH, Na OS, Kim GJ, Oh WK, Lee YD. Desalinated underground seawater of Jeju Island (Korea) improves lipid metabolism in mice fed diets containing high fat and increases antioxidant potential in t-BHP treated HepG2 cells. Nutrition research and practice, 4: 3-10, 2010.

Philips N, Auler S, Hugo R, Gonzalez S. Beneficial regulation of matrix metalloproteinases for skin health. Enzyme Research, 2011: 427285, 2011.

Ryu JY, Rhie SJ, Lim KH, Choi YE, Han HS, Yang HO, Na EJ. Inhibitory effects of prunin on photo-aging in human keratinocytes (HaCaT) damaged by UVB radiation. Asian Journal of Beauty and Cosmetology, 17: 139-147, 2019.

Sansilvestri-Morel P, Rupin A, Jullien ND, Lembrez N, Mestries-Dubois P, Fabiani JN, Verbeuren TJ. Decreased production of collagen type III in cultured smooth muscle cells from varicose vein patients is due to a degradation by MMPs: possible implication of MMP-3. Journal of Vascular Research, 42: 388-398, 2005.

Sarker S, Nahar L. Natural medicine: the genus Angelica. Current Medicinal Chemistry, 11: 1479-1500, 2004.

Sjerobabski-Masnec I, Šitum M. Skin aging. Acta Clinica Croatica, 49: 515-518, 2010.

Son CY, Baek IH, Song GY, Kang JS, Kwon KI. Pharmacological effect of decursin and decursinol angelate from Angelica gigas Nakai. Yakhak Hoeji, 53: 303-313, $2009 a$.

Son SH, Kim MJ, Chung WY, Son JA, Kim YS, Kim YC, Kang SS, Lee SK, Park KK. Decursin and decursinol inhibit VEGF-induced angiogenesis by blocking the activation of extracellular signal-regulated kinase and c-Jun N-terminal kinase. Cancer Letters, 280: 86-92, 2009b.

Song M, Lee J, Kim YJ, Hoang DH, Choe W, Kang I, Kim SS, Ha J. Jeju magma-seawater inhibits $\alpha$-MSH-induced melanogenesis via CaMKK $\beta-A M P K$ signaling pathways in B16F10 melanoma cells. Marine Drugs, 18: 473, 2020.

Yao C, Lee DH, Oh JH, Kim MK, Kim KH, Park CH, Chung $\mathrm{JH}$. Poly $(\mathrm{I}: \mathrm{C})$ induces expressions of MMP-1, -2 , and -3 through various signaling pathways including IRF3 in human skin fibroblasts. Journal of Dermatological Science, 80: 54-60, 2015.

Yoo MA, Song YK, Jang H, Kim DM, Byun SY. Profiling of skin anti-aging proteins in human dermal fibroblasts by decursin in Angelica gigas Nakai. Korean Journal of Chemical Engineering, 28: 880-885, 2011.

Zhang J, Li L, Jiang C, Xing C, Kim SH, Lü J. Anti-cancer and other bioactivities of Korean Angelica gigas Nakai (AGN) and its major pyranocoumarin compounds. Anti-Cancer Agents in Medicinal Chemistry, 12: 1239-1254, 2012. 


\title{
국문초록
}

\section{제주 용암해수로 숙성된 참당귀(Angelica gigas Nakai) 뿌리 추출물과 지표물질 데 커신(Decursin)의 인간 진피섬유아세포 내 MMP3 발현 억제 효과}

\author{
강정욱, 남가람 ${ }^{2}$, 윤예화 ${ }^{2}$ 김경미 ${ }^{2}$, 배소원 $^{2}$, 이현정 $^{2}$, 배승희 $^{2}$, 차영권 $^{3}$, 조현대 ${ }^{3}$, 조항의 ${ }^{2,3^{*}}$ \\ ${ }^{1}$ 서원대학교 산학협력단, 충청북도 청주시, 한국 \\ ${ }^{2}$ 건국대학교 화장품공학과, 서울, 한국 \\ ${ }^{3}$ (주)코스메카코리아 $\mathrm{CIR}$ 연구센터, 경기도 성남시, 한국
}

목적: 최본 연구는 제주 용암해수로 숙성된 참당귀 추출물의 인간 진피섬유아세포 내 콜라겐분해효소 발현 감소 효과를 분석하고 그 효과에 대한 지표물질을 파악하는 것을 목적으로 진행되었다. 방법: 제주 용암해수를 이용해 저온숙성하여 추출한 참당귀 추 출물의 지표물질 확인을 위해 고성능 액체 크로마토그래피(HPLC) 분석을 진행하였다. 참당귀 뿌리 추출물 및 decursin의 인간 진 피섬유아세포 내 세포생존율을 측정하고 실시간 유전자증폭 정량(qRT-PCR) 분석을 통한 콜라겐분해효소 발현 변화를 분석하였 다. Decursin으로 진행한 결과와 참당귀 뿌리 추출물의 콜라겐분해효소 발현 감소 효과를 비교하여 그 상관관계를 파악하였다. 결 과: HPLC 분석 결과, 참당귀 추출물 내 주요한 지표물질로 decursin이 확인되었다. 인간 진피섬유아세포에서 참당귀 뿌리 추출물 과 decursin은 각각 $200 \mu \mathrm{g} / \mathrm{mL}, 20 \mu \mathrm{M}$ 미만의 농도에서 세포 생존율에 낮은 영향을 보였다. 또한, $M M P 3$ 발현에 대한 참당귀 뿌 리 추출물과 decursin의 감소 효과를 qRT-PCR을 통해 확인하였다. 결론: 본 연구결과를 통해 제주 용암해수로 숙성된 참당귀 뿌 리 추출물과 이 추출물로부터 순수분리된 지표물질 decursin의 콜라겐분해효소인 MMP3 발현 감소 효능을 확인하였으며, 이를 통 해 참당귀 뿌리 추출물 및 decursion은 주름개선용 기능성화장품 소재로 활용 가능함을 과학적으로 증명하였다.

핵심어: 참당귀 뿌리, Decursin, 콜라겐분해효소, 제주 용암해수, 인간 진피섬유아세포

본 연구는 중소벤처기업부와 산업통상자원부가 지원하는 월드클래스 300 프로젝트 R\&D (S2525362) 지원사업을 통해 수행된 연구결과이며, 이에 감사드립니다.

\section{참고문헌}

김가연, 이승제, 전미지, 김보민, 김근태, 강상문, 이기영, 신은진, 김상용, 김영민. 나이아신 펩타이드 융합체의 항주름 및 피부 턴오버 개선 효과. 아시안뷰티화장품학술지, 16: 243-254, 2018.

김지예, 배승희, 정진혁, 안성관, 안인숙, 김영삼. Coptis chinensis 추출물의 JNK/AP1 Axis을 통한 인간진피섬유아세포 내 MMP1. 아시안뷰티화장품학술지, 16: 427-435, 2018.

김효영, 최홍민, 김세건, 우순옥, 문효정, 한상미. 인간 각질형성세포에서 국산 동결건조 로열젤리의 피부 건강 개선 효과. 아시안뷰티화장품학술지, 18: 413-422, 2020.

류지영, 이승자, 임계화, 최영은, 한효선, 양현옥, 나은주. Prunin의 자외선 B에 의해 손상된 인간 각질형성세포 (HaCaT) 에 대한 광노화 억제 효과. 아시안뷰티화장품학술지, 17: 139-147, 2019.

배기화, 김기주, 김남영, 송재모. 제주 용암해수를 이용한 희귀식물 자란(Bletilla striata)의 기내배양. 식물생명공학회지, 39: $281-287,2012$

손추영, 백인환, 송규용, 강재선, 권광일. 신약 개발을 위한 참당귀(Angelica gigas Nakai) 추출 decursin과 decursinol angelate의 약리 작용. 약학회지, 53: 303-313, 2009.

이성훈, 배일홍, 민대진, 김형준, 박녹현, 최지예, 신진섭, 김은주, 이해광. 제주용암해수의 피부 보습 효과 연구. 대한화장 
제주 용암해수로 숙성된 참당귀(Angelica gigas Nakai) 뿌리 추출물과 지표물질 데커신(Decursin)의 인간 진피섬유아세포 내 MMP3 발현 억제 효과

품학회지, 42: 343-349, 2016.

장현희. 아세틸글루타민의 피부세포 노화억제 및 피부장벽 기능 강화효과. 아시안뷰티화장품학술지, $16: 579-589$, 2018. 


\title{
中文摘要
}

\section{济州熔岩水熟成的当归提取物和指标物质（Decursin）对人皮肤成纤维细胞中 $M M P 3$ 表达的抑制作用}

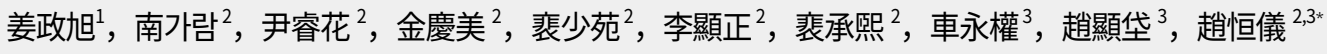 \\ ${ }^{1}$ 西原大学产学合作基金会, 忠清北道清州市, 韩国 \\ 2建国大学化妆品工学科, 首尔, 韩国 \\ ${ }^{3}$ Cosmecca Korea CIR研究中心，京畿道城南市，韩国
}

目的: 本研究旨在了解用济州熔岩水发酵的当归中草药根提取物在抑制人皮肤成纤维细胞中的胶原酶中的作 用, 并确定引起其抑制作用的主要活性化合物。方法: 通过在济州熔岩水中低温发酵制备归中草药根提取物, 并使用高效液相色谱（HPLC）分析以鉴定这些发酵根提取物中的主要活性成分。进行水溶性四唑盐（WST1）测定和实时聚合酶链反应（qRT-PCR），以研究细胞活力和胶原酶基因的表达水平。使用归中草药根提取 物和decursin进行了比较实验, 以确认胶原酶表达的下调并分析它们之间的相关性。结果: HPLC分析表明, decursin是归中草药根提取中的主要活性化合物。通过WST-1分析获得的数据显示, 对归中草药根提取的浓度 为 $200 \mu \mathrm{g} / \mathrm{mL}$, 对decursin的浓度为 $<20 \mu \mathrm{M}$ 时，对人皮肤成纤维细胞没有任何细胞毒性。 qRT-PCR分析显示， 归中草药根提取和decursin下调了人类皮肤成纤维细胞中基质金属蛋白酶3（MMP3）基因的表达。结论: 这些 分析表明, 用济州熔岩水发酵的当归中草药根提取物以及从这些提取物中分离出的 decursin具有很大的潜力, 可在化妆品中用作功能性抗皱剂。

关键词: 当归根, Decursin, 胶原酶, 济州熔岩水, 皮肤成纤维细胞 